UDC $351.74 / .76(497.11)$

Dr Tomica Delibašić

\title{
USTAVNOST ZAKONSKOG POJMA I TRETMANA PREKRŠAJA PROTIV JAVNOG REDA I MIRA*
}

Zakon o javnom redu i miru iz 2016. godine, koji je na snazi, ograničava svoju primenu na radnje preduzete na javnom mestu, čime se sužava koncepcija i zaštitna funkcija zakona koji nije sveobuhvatan u zaštiti građana i njihovih prava, pa se postavlja pitanje ustavnosti takvih zakonskih rešenja. U vezi sa time je bila podneta incijativa za ocenu ustavnosti Ustavnom sudu i o tome će prethodno biti reči.

\section{TRAGOM JEDNE INICIJATIVE ZA OCENU USTAVNOSTI ZAKONA O JAVNOM REDU I MIRU}

Inicijativa je bila podneta, odnosno naslovljena predlogom ,za ocenu ustavnosti Zakona o javnom redu i miru (Službeni glasnik RS, br. 6/2016), u delu u kome se javni red i mir vezuje za javno mesto, a isključuju se, odnosno nemaju se u vidu povrede javnog reda i mira uopšte, naročito lična i imovinska prava svih građana garantovana Ustavom, već se zakonom ne obuhvataju i ne štite recimo porodični odnosi i radnje preduzete u stanu i drugim prostorima koje zakon ne smatra javnim mestom“.

U podnetoj inicijativi je navedeno sledeće:

„Inicijativa se podnosi na osnovu čl. 168. st. 2. Ustava R. Srbije (Službeni glasnik $R S$, broj 98/2006), prema kojoj odredbi svako fizičko lice ima pravo na inicijativu za pokretanje postupka za ocenu ustavnosti i zakonitosti.

\footnotetext{
${ }^{*}$ Rad primljen 2. 10. 2017. godine.
} 
Zakonom o javnom redu i miru (Službeni glasnik $R S$, broj 6/2016) u čl. 1. je propisano da se ovim zakonom uređuje javni red i mir na javnom mestu, utvrđuju se protivpravna dela protiv javnog reda i mira, kao i način prikupljanja dobrovoljnih piloga.

Ovim se menja dotadašnja koncepcija Zakona o javnom redu i miru (Službeni glasnik $R S$ br. 51/92, 53/93, 67/93, 48/94, 101/06 - dr. zakon i 85/05 - dr. zakon), koji je u čl. 1. predviđao da se odnosi na prekršaje i krivična dela kojima se ugrožavaju i remete javni red i mir, dakle uopšte imajući u vidu javni red i mir i ne vezujući izvršenje dela samo za javno mesto, kako je učinjeno u sada važećem zakonu.

Raniji zakon je istina u čl. 2. govorio o javnom mestu, ali taj pojam nije bliže definisao i ograničavao, već je ujedno govorio o jednakim uslovima za ostvarivanje prava građana na ličnu i imovinsku sigurnost, mir i spokojstvo, privatni život, slobodu kretanja, očuvanju javnog morala i ljudskog dostojansta i prava maloletnika na zaštitu. Zato nije zakon bio ograničen na dela izvršena na javnom mestu u užem smislu tog pojma, te nije bilo ustavnih problema u njegovom tumačenju i primeni.

Važeći Zakon o javnom redu i miru (Službeni glasnik RS, br. 6/2016) se u čl. 3. bavi značenjem izraza u zakonskom tekstu, pa se bavi posebno definisanjem pojma javnog reda i mira a odvojeno pojmom javnog mesta, kao i pojmom prekršaja protiv javnog reda i mira. Tako nastaju problemi koji imaju ustavne implikacije.

U čl. 3. st. 1. tački 1) Zakona o kom je reč, koji treba ispitati sa ustavnog aspekta, definiše se javni red i mir i kaže da to: - jeste usklađeno stanje međuljudskih odnosa građana nastalo njihovim ponašanjem na javnom mestu i delovanjem organa i organizacija u javnom životu radi obezbeđenja jednakih uslova za ostvarivanje ljudskih i manjinskih prava i sloboda građana zajemčenih Ustavom. Dalje se u tački 2) definiše javno mesto, pa kaže da to: - jeste prostor dostupan neodređenom broju lica čiji identitet nije unapred određen, pod istim uslovima ili bez posebnih uslova. Tačka 3) daje pojam prekršaja protiv javnog reda i mira, da to: - jesu protivpravna dela kojima se na javnom mestu ugrožava ili narušava javni red i mir, stvara uznemirenje ili ugrožava sigurnost građana, ometa kretanje građana na javnim mestima ili ostvarivanje njihovih prava i sloboda, vređa moral, ugorožava opšta sigurnost imovine, vređaju ili ometaju službena lica ili se na drugi način narušava javni red i mir.

Zakonodavac je u čl. 3. st. 2) propisao i sledeće: - Smatraće se da je prekršaj ili krivično delo iz ovog zakona izvršeno na javnom mestu i kad je radnja izvršenja na mestu koje se u smislu st. 1. t. 2) ovog člana ne smatra javnim mestom, ako je to mesto dostupno pogledu ili čujnosti sa javnog mesta ili je posledica nastupila na javnom mestu.

Pre svega su sa ustavnog aspekta sporne citirane odredbe čl. 1. i čl. 3. t. 1), 2) i 3), i st. 2. istog člana Zakona o javnom redu i miru, gde se datim pojmovima i definicijama vrše ograničenja zaštite od dela koja su izvršena na 
javnom mestu, a nema u vidu opšta i jednaka zaštita ličnih i imovinskih prava, bez obzira gde su preduzete radnje povrede i ugrožavanja.

Dakle, imamo nejednak tretman sloboda i prava građana, zavisno od toga da li su ili nisu radnje ugrožavanja preduzete na javnom mestu. Na ovaj način je zaštita građanskih sloboda i prava bitno ograničena i postoji njihov nejednak tretman. U prvi plan se stavlja dostupnost javnog mesta drugim licima, te da li je došlo do uznemirenja ili ugrožavanja sigurnosti građana, dakle trećih lica, a ne štiti se pravo neposredno oštećenog i ugroženog, ili bar ne u jednakoj i dovoljnoj meri. Kada se u čl. 3. st. 2. pokušava proširiti pojam izvršenja prekršaja na javnom mestu, u slučaju kada je prekršaj izvršen na mestu koje se ne smatra javnim mestom, to se ograničava traženjem da je „to mesto dostupno pogledu ili čujnosti sa javnog mesta ili je posledica nastupila na javnom mestu“. Dakle, to navodno širenje pojma javnog mesta se opet ograničava javnim mestom, jer se traži dostupnost ili čujnost sa javnog mesta ili da je posledica nastupila na javnom mestu. Sve se opet vezuje za javno mesto. Krug se zatvara na javnom mestu i sve za to vezuje. Povrede i ugrožavanja prava i sloboda van javnog mesta se tako ne sankcionišu ni na koji način.

Ako se u čl. 3. st. 1. Zakona govori o jednakim uslovima za ostvarivanje ljudskih i manjinskih prava i sloboda građana zajemčenih Ustavom, to je suštinski deklaracija bez pokrića, jer iz ostalih odredbi jasno prozlazi da se ne radi o jednakoj zaštiti.

Stan se po citiranom Zakonu ne smatra javnim mestom, što je centralni problem, pa se time ne štiti porodično nasilje niti drugo nasilje izvršeno u stanu, pa se postavlja pitanje tretmana povreda i prekršaja koji nemaju težinu krivičnih dela. Ni na obuhvatnost krivične zaštite ne može računati, naime da se tako ovo zakonsko rešenje ispravi, ili čak objasni, kako neki smatraju, niti to može biti objašnjenje nejadnakog zakonskog tretmana građana kao oštećenih, zavisno od toga da li se ugrožavanje prava dogodilo na javnom mestu, kako ga zakon definiše. Ako galamu i radnje remećenja mira komšija čuje u susednom stanu, taj drugi stan takođe nije javno mesto i to nema pravnog značaja, prema st. 2. čl. 3. Zakona. Time se stimuliše porodično i slično nasilje, preduzeto u stanu i prostorima nedostupnim drugim licima. I kod dvorišta se praksa koleba, ceneći da li je ono bilo dostupno pogledu ili čujnosti sa javnog mesta. Smatra se da zakon traži se da dostupnost pogledu i čujnosti treba da bude konkretizovana, da je neko video ili čuo remećenje i time bio uznemiren, da to zakon predviđa. Zato su u drugom planu lične povrede prava oštećenog, nad kojim se recimo vrši nasilje, jer zavisno od mesta gde su preduzete mogu biti nerelevantne. Tako imamo povrede javnog reda i mira, pre svega usmerene na ličnost građana i njegovu imovinu, koje su pravno nezaštićene.

Nasilje u porodici pre svega na ovaj način je bez odgovarajuće pravne zaštite, pa su nakon stupanja na snagu spornog Zakona o javnom redu i miru 
oslobođeni prekršajne odgovornosti učinioci koji su prekršaje učinili u stanu, jer se stan ne smatra javnim mestom. Novi zakon je na njih primenjen kao blaži, nalazeći da ta radnja nije propisana kao prekršaj. Ovo bez obzira ne nesporno činjenično stanje i dokaze izvedene po ranijem zakonu i da je u stanu došlo do narušavanja javnog reda i mira. Nekada se ne radi o porodičnom, već komšijskom nasilju. U daljoj praksi se takvi postupci ne pokreću i ne vode, već samo za prekršaje preduzete na javnom mestu, kako ga Zakon definiše. Uzmimo i sličaj uznemiravanja i pretnji SMS porukama, jer ni to nije prekršaj izvršen na javnom mestu, osim ako se oštećeni zatekao na javnom mestu gde ga neko čuje i vidi, pa su i ti učinioci oslobođeni odgovornosti. To su očigledne zakonske nelogičnosti, koje su ustavno neprihvatljive.

Podnosi se par kopija presuda iz kojih se vide navedena pitanja i postupanja prakse, primenom novog odnosno važećeg Zakona o javnom redu i miru.

Postoje krivična dela nasilja u porodici, kao i nasilničkog ponašanja, ali ona ne mogu obuhvatati sve radnje ove vrste, jer praksa logično ceni težinu dela i ugrožavanja sloboda i prava, zato sva ovakva dela ne mogu biti krivično delo, pa krivičnopravna zaštita ne može biti objašnjenje za nejednak tretman građana kod propisivanja prekršaja javnog reda i mira, niti zakon treba sadržavati ograničenja o kojima je reč. Naime, prema čl. 21. Ustava, svi su pred ustavom i zakonom jednaki i svako ima pravo na jednaku zaštitu bez diskriminacije, a ova ustavna odredba je povređena.

Zato se podnosi inicijativa za ocenu ustavnosti Zakona o javnom redu i miru (Službeni glasnik RS, br. 6/2016), u delu u kome se javni red i mir vezuje za javno mesto, i način kako se to mesto definiše i vrše navedena ograničenja, nejednakim tretmanom građana oštećenih delima povrede javnog reda $\mathrm{i}$ mira. Predlaže se da Ustavni sud sve ovo ispita.“

Da vidimo kako je Ustavni sud ocenio inicijativu.

Ustavni sud, Malo veće, je zaključkom Iuz-205/2016 na sednici od 8 . novembra 2016. godine odbacio inicijativu za pokretanje postupka za ocenu ustavnosti odredbi čl. 1. i čl. 3. st. 1. t. 1) do 3) i st. 2. Zakona o javnom redu i miru (Službeni glasnik $R S$, broj 6/16), navodeći nakon skraćene interpretacije inicijative, sledeće:

„Razmatrajući podnetu inicijativu u smislu navoda i razloga za osporavanje, Ustavni sud je utvrdio da podnosilac inicijative u stvari iznosi samo svoja mišljenja, neslaganja i tumačenja osporenih odredaba Zakona, kao i potrebu za drugačijim uređenjem pojedinih pitanja, imajući u vidu rešenja iz prethodno važećeg Zakona o javnom redu i miru iz 1992. godine, bez navođenja ustavnopravnih razloga za osporavanje odredaba čl. 1. i čl. 3. st. 1. t. 1) do 3) i st. 2. važećeg Zakona o javnom redu i miru, kojima je samo određen 
predmet uređenja ovog zakona i dato značenje pojedinih izraza koji su u njemu upotrebljeni.

Saglasno navedenom, Ustavni sud je zaključio da, u konkretnom slučaju, formalno isticanje zahteva za ocenu ustavnosti ne može imati značenje inicijative za pokretanje postupka, kao i da Ustavni sud, saglasno odredbama čl. 167. Ustava, nije nadležan da ceni celishodnost predviđenih rešenja, njihovu primenu u praksi, niti predloge za drukčije uređenje pojedinih pitanja. Iz tih razloga Ustavni sud je, saglasno odredbi čl. 36. st. 1. t. 7) Zakona o ustavnom sudu (Službeni glasnik RS, br. 109/07, 99/11, 18/13 - Odluka US, $40 / 15$ - dr. zakon i 103/15), podnetu inicijativu odbacio, zbog nepostojanja pretpostavki za vođenje postupka i odlučivanje u ovom predmetu.

Polazeći od svega izloženog, Ustavni sud je, na osnovu čl. 42b st. 1. t. 2) i čl. 47. st. 2. Zakona o ustavnom sudu, doneo Zaključak kao u izreci““.

Tako je prošla navedena incijativa.

Kako se Ustavni sud pozvao na čl. 36. st. 1. t. 7. Zakona o ustavnom sudu, to znači da ,ne postoje druge pretpostavke za vođenje postupka i odlučivanje, utvrđene zakonom“.

Iz navedenog se može zaključiti da se Ustavni sud nije ni osvrnuo, a kamoli cenio, navode inicijative o ,nejednakom tretmanu građana kod propisivanja prekršaja javnog reda i mira“, dakle da u tom smislu ispita inicijativu, odnosno sa aspekta ustavnosti ispita Zakon o javnom redu i miru ,u delu u kome se javni red i mir vezuje za javno mesto, i način kako se to mesto definiše i vrše navedena ograničenja, nejednakim tretmanom građana oštećenih delima povrede javnog reda i mira“. Ovo zato što su, kako se u incijativi navodi, ,prema čl. 21. Ustava, svi pred ustavom i zakonom jednaki i svako ima pravo na jednaku zaštitu bez diskriminacije, a ova ustavna odredba je povređena“. U inicijativi je istaknuto da se zakonskim ,datim pojmovima i definicijama vrše ograničenja zaštite od dela koja su izvršena na javnom mestu, a nema u vidu opšta i jednaka zaštita ličnih i imovinskih prava, bez obzira gde su preduzete radnje povrede i ugrožavanja“.

Pitanje je kako se ceni predmet i suština incijative, da se ustavnost Zakona osporava jer se kod zakonskog predmeta zaštite nemaju u vidu povrede javnog reda i mira uopšte, već samo one učinjene na javnom mestu, a da su sa druge strane lična i imovinska prava svih građana jednako garantovana Ustavom.

Teško je shvatljivo obrazloženje Ustavnog suda, da je incijativa „bez navođenja ustavnopravnih razloga za osporavanje odredaba čl. 1. i čl. 3. st. 1. t. 1) do 3) i st. 2. važećeg Zakona o javnom redu i miru, kojima je samo određen predmet uređenja ovog zakona i dato značenje pojedinih izraza koji su u njemu upotrebljeni“،. Podnosilac incijative nije ni podneo ustavnu žalbu, kada bi postojala vezanost Suda za navode i predloge podnosioca, već se radi o incijativi 
za ocenu ustavnosti, što je dužnost suda da i po službenoj dužnosti ceni, a da je bilo dovoljno na bitno ukazati. To je prevashodni zadatak ovog suda. Podnosilac inicijative (inače pisac ovog teksta) se možda previše pouzdao u Ustavni sud, da je izneto svakome jasno, time dovoljno, a da će Sud po službenoj dužnosti svakako ispitati ustavnost navedenih zakonskih rešenja, koja rešenja diraju u čitavu koncepciju zakona, naime bilo je za očekivati da će Ustavni sud poći od čl. 54. Zakona o ustavnom sudu, gde je propisano: „U postupku ocenjivanja ustavnosti ili zakonitosti Ustavni sud nije ograničen zahtevom ovlašćenog predlagača, odnosno inicijatora“", pa da čak kada ovlašćeni predlagač, odnosno inicijator odustane od predloga, odnosno inicijative, Ustavni sud će nastaviti postupak za ocenu ustavnosti ili zakonitosti, ako za to nađe osnova. Praktični primeri koji su u inicijativi dati samo je trebalo da ukažu na ozbiljnost problema sa ustavnopravnog aspekta, da se vidi suština i lakše ceni ustavnost zakona. To što se postavlja pitanje ustavnosti samog predmeta zakona i njegovih osnovnih pojmova, koja određuju prirodu zakona, kao što je pojam javnog reda i mira koji se ograničava i nedopustivo sužava, ukazuje na širu spornost koncepcije zakona sa aspekta istaktnute sporne ustavnosti, odnosno nejednakog tretmana oštećenih, i time je problem ozbiljniji. Da li je Ustavni sud sve to adekvatno cenio i koliko je bio na visini svog zadatka, ostavljam čitaocima da prosude.

\section{PRIMERI IZ PRAKSE KOJI UKAZUJU NA PROBLEM USTAVNOSTI ZAKONSKIH REŠENJA}

Odmah na početku primene važećeg Zakona o javnom redu i miru postavilo se kao sporno pitanje da li se taj zakon može primeniti na bilo koju radnju preduzetu van javnog mesta, pa da istaknemo presude koje su bile podnete uz incijativu, koje to ilustruju.

Naime, Vrhovni kasacioni sud je presudom Kzz Pr 13/2016 od 26. 4. 2016. godine uvažio zahtev za zaštitu zakonitosti Republičkog javnog tužioca i ukinuo pravnosnažnu presudu Prekršajnog apelacionog suda, navodeći između ostalog sledeće:

„Novim Zakonom o javnom redu i miru (Službeni glasnik $R S$, broj 6/16) koji je stupio na snagu 5. 2. 2016. godine vređanje i ugrožavanje pretnjom van javnog mesta, više nije prekršaj, pa se prema novom Zakonu o javnom redu i miru u radnjama okrivljenih ne stiču elementi prekršaja za koji su oglašeni odgovornim.“

U jednom drugom slučaju, koji je takođe prezentovan, okrivljeni su zahtevom za pokretanje prekršajnog postupka terećeni zbog remećenja javnog 
reda i mira vršenjem nasilja nad drugim, odnosno prekršaj iz čl. 6. st. 3. ranijeg Zakona o javnom redu i miru, ali ih je prvostepeni sud oslobodio odgovornosti, jer se radnja sastoji u vršenju nasilja nad drugim u porodičnoj kući, koja radnja čl. 9. važećeg Zakona o javnom redu i miru nije prekršaj, jer nije narušen javni red i mir pošto se događaj odigrao van javnog mesta, a porodična kuća nije bila dostupna pogledu niti čujnosti sa javnog mesta, pa ni posledica nije nastupila na javnom mestu.

Podnosilac zahteva za pokretanje prekršajnog postupka je osporio obustavu postupka i u žalbi naveo da se radi o težem prekršaju narušavanja javnog reda i mira i da su radnje objektivno bile dostupne pogledu ili čujnosti sa javnog mesta, što se pre svega odnosi na komšije, ali i postupajuća službena lica policije ili zdravstvenih ustanova u kojima je oštećeno lice zbrinuto.

Žalbu je odbio Prekršajni apelacioni sud presudom Prž. Br. 14742/16 od 26. 7. 2016. godine, navodeći između ostalog sledeće:

„Prema odredbama kasnijeg Zakona o javnom redu i miru radnja vršenja nasilja nad drugim koja nije izvršena na javnom mestu ima značaj prekršaja samo pod uslovom da je mesto na kojem je ta radnja izvršena bilo dostupno pogledu ili čujnosti sa javnog mesta, pri čemu iz činjeničnog opisa datog u podnetom zahtevu za pokretanje prekršajnog postupka proizlazi da su se okrivljeni i oštećena kritičnom prilikom nalazili u porodičnoj kući, što je u toku sprovedenog postupka učinjeno nespornim. Istovremeno, navodi podnetog zahteva, kao ni iskazi okrivljenih, odnosno sadržina izvedenih dokaza, koji su priloženi podnetom zahtevu, ne predstavljaju osnov za zaključak da je mesto izvršenja predmetnih radnji bilo dostupno pogledu ili čujnosti sa javnog mesta, odnosno da je posledica nastupila na javnom mestu. S tim u vezi, neophodno je naglasiti da dostupnost mesta izvršenja konkretne radnje pogledu ili čujnosti sa javnog mesta, po prirodi stvari, može biti smatrana nespornom isključivo pod uslovom da je određeno lice, ili više njih, videlo ili čulo zbivanja na tom mestu u vreme izvršenja same radnje, kao što se, shodno tome, konkretna radnja ima smatrati izvršenom na javnom mestu ako je posledica radnje nastupila na javnom mestu, dakle ne i u slučaju da je, s obzirom na okolnosti, postojala mogućnost nastupnja posledice na javnom mestu.“

Navedeni slučajevi završavaju se tako da se ima smatrati da je dozvoljeo vršenje nasilja nad drugim, kao i vršenje drugih sličnih radnji (svađa, vika, buka, nepristojno, drsko i bezobzirno ponašanje, vređanje, vršenje nasilja, pretnja i tuča) koje su izvršene van javnog mesta. Time se pospešuje vršenje kućnog i drugog nasilja van javnog mesta, što se čini u eri kampanje o zaštiti žrtava porodičnog nasilja, koja je na ovaj način ozbiljno diskreditovana.

Navešćemo primer i novije sudske prakse. Okrivljeni je po ovom osnovu oslobođen odgovornosti za prekršaj iz čl. 9. st. 1. Zakona o javnom redu i miru, 
na osnovu odredbe čl. 250. st. 1. t. 1. Zakona o prekršajima, jer delo za koje se okrivljeni tereti nije propisano kao prekršaj. Okrivljenom je inače zahtevom bilo stavljeno na teret da je u svojoj porodičnoj kući remetio javni red i mir, na taj način što je oštećenom, koji nije član njegove porodice, zadao više udaraca šakom u predelu glave, usled čega je to lice palo na pod. Postojalo je i treće lice koje je navedeno kao svedok. Međutim, sud je naveo da mesto izvršenja radnje nije bilo dostupno pogledu i čujnosti sa javnog mesta, niti je posledica radnje nastupila na javnom mestu, budući da se radnja dogodila u porodičnoj kući, pa radnja vršenja nasilja nad drugim u konkretnom slučaju nije prekršaj iz čl. 9. st. 1. Zakona o javnom redu i miru, koja postoji kao prekršaj ako je narušen javni red i mir, što u konkretnom predmetu nije slučaj. Zato je zaključeno da delo za koje se okrivljeni tereti nije propisano kao prekršaj, imajući u vidu odredbe čl. 3. st. 1. t. 1. i st. 2. Zakona o javnom redu i miru, koje odredbe se citiraju. Nekada se radi i o prisustvu policije, jer je nasilje nastavljeno i u njenom prisustvu, što nije bitno za pojam javnog reda i mira, jer se ne radi o javnom mestu.

Podnosilac zahteva za pokretanje prekršajnog postupka je u žalbi naveo da je okrivljeni oštećenom zadao više udaraca u predelu glave i ovaj je doživeo telesne povrede, što nije sporno niti to oštećeni i okrivljeni osporavaju, a samo prisustvo oštećenog i svedoka u stanu okrivljenog, čije saslušanje je predloženo, kao i pozivanje hitne pomoći, jeste prisustvo neodređenog broja lica čiji identitet nije unapred određen, pod istim uslovima ili bez posebnih uslova.

Žalba podnosioca zahteva je odbijena sa sledećim obrazloženjem.

„Odredbom čl. 3. st. 2. t. 1. i t. 2. Zakona o javnom redu i miru (Službeni glasnik $R S$, br. 6/2016) izričito je propisano da je javni red i mir usklađeno stanje međusobnih odnosa građana nastalo njihovim ponašanjem na javnom mestu, a da se javno mesto označava kao prostor dostupan neodređenom broju lica čiji identitet nije unapred određen, pod istim uslovima ili bez posebnih uslova, dok je st. 2. istog člana propisano da će se smatrati da je prekršaj iz ovog zakona izvršen na javnom mestu i kada je radnja izvršenja na mestu u smislu st. 1 . i t. 2 . koje se ne smatra javnim mestom, i to ako je to mesto dostupno pogledu ili čujnosti sa javnog mesta ili je posledica nastupila na javnom mestu, tako da se u smislu citiranih odredbi stan, odnosno porodična kuća kao mesto izvršenja prekršaja u ovom slučaju ne mogu smatrati javnim mestom, te su se stekli uslovi da se okrivljeni oslobodi odgovornosti za prekršaj koji mu se zahtevom za pokretanje prekršajnog postupka stavlja na teret, odnosno da se primeni čl. 250. st. 1. t. 1. Zakona o prekršajima." (Prekršajni apelacioni sud, Prž. 15816/17 od 7. 9. 2017. godine)

Tako se i ovi usamljeni pokušaji podvođenja nespornog vršenja nasilja nad drugim pod odredbe Zakona o javnom redu i miru, pa i pozivom na prisustvo svedoka, završavaju bezuspešno. 
Isto se odnosi na pozive, pretnje i uvrede izvršene telefonom, pa i upućene na dežurni policijski broj, kao i sms poruke upućene takođe preko telefona, jer se zaključuje da radnje nisu izvršene na javnom mestu. Sve takve slučajeve nije moguće navesti, a oni su brojni.

Tako se od uznemiravanja ne štiti neposredno oštećeni, već praktično javno mesto i samo treća lica zatečena na javnom mestu, jer se ceni da li su ona čula vršenje nasilja i bila uznemirena, a ne štiti neposredno ugroženi građanin i njegov integritet bez izuzetka. Samo pojedina lica mogu računati na zaštitu Zakona o javnom redu i miru, i to zato što se nasilje dogodilo na javnom mestu, a ne zato što se štite prava i slobode građanina, pa čak ni konkretnog oštećenog.

Zanimljivo je da su, prema mom saznanju, u kreiranju spornih rešenja Zakona o javnom redu i miru učestvovali praktičari, kao i da navedeno stanje traje, brojni postupci su obustavljeni ili se ne vode. Sve izneto kompromituje pravosudni sistem i javni poredak uopšte.

\section{DRUGA ZAKONSKA REŠENJA \\ U VEZI SA NAVEDENIM PITANJEM}

Zakon o sprečavanju nasilja u porodici (Službeni glasnik RS, br. 94/2016), ne bavi se sankcionisanjem nasilja u porodici, koje bi se smatralo redom i mirom, već se bavi postupanjem državnih organa i ustanova u sprečavanju nasilja u porodici i pružanju zaštite i podrške žrtvama nasilja u porodici.

Sledstveno tome, jedini prekršaj koji se propisuje ovim zakonom je onaj iz čl. 36, gde je u st. 1. propisano da će se kaznom zatvora do 60 dana kazniti za prekršaj lice koje prekrši hitnu meru koja mu je izrečena ili produžena. Ovakvi slučajevi se u praksi događaju i tu se prekršajna primena ovog zakona praktično završava. Tu je i prekršaj iz st. 2. da će se novčanom kaznom od 50.000 do 150.000 dinara kazniti za prekršaj odgovorno lice u državnom ili drugom organu, organizaciji i ustanovi koje policiji ili javnom tužilaštvu neodložno ne prijavi ili ne reaguje na prijavu ili opstruira prijavljivanje ili reagovanje na svako saznanje o nasilju u porodici ili neposrednoj opasnosti od njega (čl. 13. st. 2).

Nasilje u porodici se čl. 3. st. 3. Zakona o sprečavanju nasilja u porodici definiše kao akt fizičkog, seksualnog, psihičkog ili ekonomskog nasilja učinioca prema licu sa kojim se učinilac nalazi u sadašnjem ili ranije bračnom ili vanbračnom ili partnerskom odnosu ili prema licu sa kojim je krvni srodnik u pravoj liniji, a u pobočnoj liniji do drugog stepena ili sa kojim je srodnik po tazbini do drugog stepena ili kome je usvojitelj, usvojenik, hranjenik ili hranitelj ili prema drugom licu sa kojim živi ili je živeo u zajedničkom domaćinstvu. 
Nije predmet ovog zakona da sankcioniše radnje narušavanja javnog reda i mira koje je ispustio da propiše Zakon o javnom redu i miru, kada se ograničio na radnje preduzete na javnom mestu i to mesto suzio tako da su izvan zaštite ostale brojne radnje, pre svega preduzete u stanu ili porodičnoj kući, odnosno van pogleda i čujnosti sa javnog mesta. Bez zaštite su radnje nasilja i druge radnje koje opisuje Zakon o javnom redu i miru, ali ih u celosti ne obuhvata, jer su preduzete van javnog mesta, dakle selektivno ih štiti. Nisu to samo radnje koje nekada mogu biti nasilje u porodici, u smislu Zakona o sprečavanju nasilja u porodici, jer radnje ne moraju biti preduzete od pobrojanih lica, već od drugih lica zatečenih u stanu ili porodičnoj kući. Ono što je propustio Zakon o javnom redu i miru nije moglo biti obuhvaćeno i kazneno zaštićeno drugim zakonom, jer ne postoji zakon koji reguliše povrede reda i mira koje nisu preduzete na javnom mestu, a ne bi bilo ozbiljno da takav zakon postoji i da se predmet pravne zaštite tako deli.

Isto se odnosi na krivično delo nasilja u porodici iz čl. 194. Krivičnog zakonika (Službeni glasnik RS, br. 85/2005 do 94/2016), jer se odnosi na člana porodice i mora imati intenzitet odnosno stepen opasnosti koju prevazilazi prekršaj, uopšteno govoreći. Krivično delo se čini primenom nasilja, pretnjom da će napasti život ili telo, drskim i bezobzirnim ponašanjem kojim se ugrožava spokojstvo, telesni integritet ili duševno stanje člana svoje prodice. Dakle, ne samo da se primena ograničava na člana porodice, već su van domašaja brojne druge radnje preduzete van javnog mesta, a koje objektivno opisuje Zakon o javnom redu i miru, ali je preme njima indiferentan, čineći ih čak dozvoljenim. Time se pospešuje ne samo vršenje nasilja u porodici, već i šire kršenje mira i reda preduzeto van javnog mesta. Može se postaviti pitanje da li je slučajno što su radnje nasilja u porodici i one šire preduzete van javnog mesta sve učestalije i da li za to snosi „krivicu“ Zakon o javnom redu i miru.

Takođe i krivično delo nasilničkog ponašanja iz čl. 34. Krivičnog zakonika, koje poznaje pojam javnog reda i mira, kaže da delo postoji ako se „značajnije ugrožava spokojstvo građana ili teže remeti javni red i mir", dakle izvan toga su blaže radnje koje bi trebalo podvesti pod prekršaj, ali kao što smo videli Zakon o javnom redu i miru nema takav pristup, kada javni red i mir vezuje isključivo za javno mesto i ispušta ostale radnje, preduzete na drugim mestima.

Besmisleno bi bilo i takođe protivustavno, radnje koje je zanemario $\mathrm{Za}-$ kon o javnom redu i miru prepustiti podzakonskoj regulativi, odnosno opštinskim odlukama, o kućnom redu i sličnim odlukama (to i nije njihov predmet), jer bi to bio neravnopravan tretman građana i zaštite njihovih prava, a radnjama preduzetim van javnog mesta bi bio pridavan manji značaj, po visini zaprećenih kazni koje su blaže nego zakonske. 
Problem se može rešiti jedino donošenjem novog Zakona o javnom redu i miru, jer je teško izmenama zakona menjati njegovu osnovnu koncepciju. Jednostavno, moraju biti zakonski sankcionisani prekršaji nezavisno da li su izvršeni na javnom mestu ili van javnog mesta, i to pre svega: svađa, vika i buka na javnom mestu (čl. 7), nepristojno, drsko i bezobzirno ponašanje (čl. 8), vređanje, vršenje nasilja, pretnja ili tuča (čl. 9), prostitucija (čl. 16). Da li neke radnje preduzete na javnom mestu mogu biti kvalifikatorne i treba li neko posebno delo u vezi sa tim, pitanje je koje ne dira analizirane probleme. To znači da treba, pre svega, menjati citirani zakonski pojam prekršaja javnog reda i mira.

\section{DA LI JE TEORIJSKI SPORAN POJAM PREKRŠAJA JAVNOG REDA I MIRA?}

Kada je u pitanju teorija, već uopšten pogled na definicije pojma javnog reda i mira, kao i prekršaja javnog reda i mira, koje daju teoretičari, ukazuje da se uglavnom polazi od interpretacije zakonskog pojma prekršaja javnog reda i mira, pa da izvan toga nema ozbiljnijih analiza ovih pitanja, tim pre što se ona u bitnome nisu postavljala kao sporna, te da su posebno aktuelizovana donošenjem važećeg Zakona o javnom redu i miru. Kada su ranija zakonska rešenja govorila o prekršajima izvršenim na javnom mestu, ona su bila data tako što se pojam prekršaja protiv javnog reda i mira time nije iscrpljivao, već se radilo o segmentu tog pojma, bar je tako tumačeno i tako se moglo tumačiti, iako je sve to ponekad problematično zvučalo. Teoriji i praksi nije smetalo da takva zakonska rešenja, ponekad nedovoljno jasna, tumače bez ograničenja da se prekršaji javnog reda i mira vezuju samo za javno mesto. To znači da je problem nastao $i$ došao do izražaja sa novim zakonskim rešenjima, konkretno važećim Zakonom o javnom redu i miru.

U starijim teorijskim izvorima, kao što je Pravna enciklopedija, ${ }^{1}$ javni red i mir prethodno se uopšteno određuje kao „međusobni odnosi građana koji su u skladu sa pravilima ponašanja o normalnom načinu života i društvenoj disciplini”. To je opšti pojam. Potom se kaže: „Ponašanja i postupci kojima se remeti normalan način života građana, ugrožava njihova bezbednost, remeti nesmetano kretanje lica na javnim mestima, unosi nemir među građane, narušava javni moral, ometa korišćenje javnih objekata, stambenih i drugih zgrada, ometa rad i izvršenje služebnih zadataka državnih organa, organizacija udruženog rada i drugih organizacija koje vrše javna ovlašćenja ili na drugi način protivno propisima narušava društvena disciplina ili mir građana, smatraće se prekršaji-

${ }^{1}$ Pravna enciklopedija, Beograd, 1979, 489. 
ma protiv javnog reda i mira.” Dakle, širok je i sveobuhvatan pojam prekršaja protiv javnog reda i mira, a samo je jedan njegov alternativan deo remećenje nesmetanog kretanja lica na javnim mestima, i široka je lepeza drugih radnji koje se ne vezuju za javno mesto, jer bi to bilo ograničenje kojim bi se negirala i obesmislio zaštitni objekat i zaštitna funkcija ovih prekršaja. Pojedine prekršajne radnje su se i tada u zakonima vezivale za javno mesto, ali uz brojne druge radnje koje se ne tiču javnog mesta, odnosno nije bitno na kom su mestu izvršene, a ticale su se sigurnosti i mira građana i zaštite njihovih osnovnih ustavnih prava.

U novijoj teorijskoj misli se polazi od zakonske definicije Zakona o javnom redu i miru iz 1992. godine, pa se kaže: „Javni red i mir predstavljaju usklađeno stanje međusobnih odnosa ljudi nastalo njihovim ponašanjem na javnom mestu i delovanjem organa $\mathrm{i}$ organizacija $\mathrm{u}$ javnom životu radi obezbeđivanja jednakih uslova za ostvarivanje prava građana na ličnu i imovinsku sigurnost, mir i spokojstvo, privatni život, slobodu kretanja, očuvanje javnog morala i ljudskog dostojanstva i prava maloletnika na zaštitu." ${ }^{2}$ Teorija je i morala poći od zakonske definicije, ali je ne mora bezrezervno prihvatiti. Upravo se pojmovno određenje na tome ne završava, jer ovi teoretičari se ne zadovoljavaju zakonskom definicijom, već se odmah dalje kaže da je ,poštovanje javnog reda i mira istovremeno poštovanje javnog poretka koji je regulisan mnogobrojnim i raznovrsnim pravilima ponašanja", pa da se prekršajima protiv javnog reda i mira ,narušava opšta društvena disciplina koja se sastoji od harmonije međusobnih odnosa građana, funkcionisanja službi, vršenja delatnosti, vršenje prava i obaveza, što sve čini normalan tok života društvene zajednice”. Zaključuje se da je opšti zaštitni objekt kod ovih prekršaja ,javni red i mir tj. opšta društvena disciplina što čini suštinu javnog poretka jednog društva”. Dakle, iako je i raniji zakonski tekst ponašanje na javnom mestu stavljao $u$ prvi plan, time pojam i zaštitna funkcija javnog reda i mira nisu bile sasvim ograničene, bez obzira na izvesnu nespretnost citirane zakonske formulacije od koje teorija polazi. To nije bio osnov da se zaključi da nisu prekršaji sve radnje preduzete van javnog mesta, kako je po važećem zakonu, koji je sumnjivog ustavnog osnova, ako to nije sasvim očigledno. Važeći zakonski tekst ne vezuje javni red i mir za javni poredak uopšte, kako bi moralo biti, već ga vezuje za javno mesto, kao predmet regulative.

Važeći zakonski tekst je otišao u krajnost, propisujući da su prekršaji protiv javnog reda i mira protivpravna dela kojima se na javnom mestu ugrožava ili narušava javni red i mir, stvara uznemirenje ili ugrožava sigurnost građana, ometa kretanje građana na javnim mestima ili ostvarivanje njihovih prava i sloboda, vređa moral, ugorožava opšta sigurnost imovine, vređaju ili ometaju slu-

\footnotetext{
${ }^{2}$ Jovanović, dr Ljubiša, Jelačić, Milenko, Prekršaji i privredni prestupi, Beograd, 1997.
} 
žbena lica ili se na drugi način narušava javni red i mir. Sve navedene radnje se vezuju za javno mesto, pa se to odnosi na čitav zakon i on je praktično u celosti sporan i besmislen, jer se njime ne postiže zaštita sloboda i prava svih građana, već se postiže nekakva nazovi selektivna pravda.

\section{ZAKLJUČAK}

Prekršaji protiv javnog reda i mira moraju se ticati javnog, odnosno pravnog poretka uopšte, obuhvatajući sve povrede tog poretka i na jednak način štiteći prava svih građana, bez obzira gde su povrede učinjene, na javnom mestu ili van njega. U protivnom, nema zaštite sloboda i prava građana i pravni poredak ne funkcioniše. 